Teacher design teams as a strategy for professional development: The role of the facilitator

\author{
H. Becuwe ${ }^{\mathrm{a}^{*}}$, J. Tondeur ${ }^{\mathrm{a}, \mathrm{b}}$, N. Pareja Roblin ${ }^{\mathrm{a}, \mathrm{c}}$, J. Thys ${ }^{\mathrm{d}}$, E. Castelein ${ }^{\mathrm{d}}$ \\ ${ }^{a}$ Department of Educational Studies, Ghent University, Ghent, Belgium \\ ${ }^{b}$ Fonds Wetenschappelijk Onderzoek, Belgium \\ ${ }^{c}$ Learning Research and Development Center, University of Pittsburgh, USA \\ ${ }^{d}$ UC Leuven - Limburg Teacher Education, Leuven, Belgium
}




\section{Teacher design teams as a strategy for professional development: The role of the facilitator}

The goal of the current study was to explore the role and importance of the facilitator in Teacher Design Teams. The study took place in the context of a pre-service teacher education institution in Belgium, where teacher design teams were set up to facilitate the professional development of teacher educators. The findings from focus group discussions with team members and semi-structured interviews with facilitators confirm that the perceived importance of a facilitator depends on several factors, such as team characteristics and the design phase. Moreover, we found that a facilitator can fulfil three roles in a dynamic way: 1) providing logistic support, 2) scaffolding the design process and 3) monitoring the design process. The discussion centers on how these results can be used to support facilitators for successful Teacher Design Teams.

Keywords: teacher design teams; professional development; curriculum design; facilitator

\section{Introduction and background of the study}

\subsection{Professional development of teachers}

The professional development of teachers plays a crucial role in improving the quality of education and classroom practices (Loughran, 2014). Because one-day events such as seminars are not effective enough in bringing change to the teaching practice (McConnell, 2013), teachers' professional learning arrangements are shifting towards demand-driven models with teachers as active participants (Lim \& Lee, 2014). In this respect, communities of practice can play a role in the professional development of teachers and can encourage innovation (Bruining, 2007). Communities of practice are groups of people who share a concern or a passion for something they do and learn how to do it better through regular interaction (Wenger, 2011; Wenger, McDermott \& Snyder, 2002). Collaboration in communities of practice produces a common repertoire of perceptions, vocabulary and routines (Bruining, 2007). 
In education, communities of practice can take multiple forms (e.g. knowledge networks, professional learning communities). Often, communities of practice engage in collaborative design. Several studies suggest that the involvement of teachers in collaborative design constitutes an effective strategy for professional development (e.g. Bakah, Voogt \& Pieters, 2012; Simmie, 2007; Voogt et al., 2011). In this study we therefore focus on a specific form of teacher collaboration within communities of practice, known as Teacher Design Teams. A Teacher Design Team (TDT) can be described as a group of two or more teachers who (re-)design curriculum materials together (Handelzalts, 2009). A distinctive characteristic of TDTs is the sort of design task at hand. Several studies show that to facilitate a successful design process, sufficient time and support are necessary (Handelzalts, 2009; Huizinga, Handelzalts, Nieveen \& Voogt, 2015).

\subsection{The roles of facilitators}

In the context of professional development programs, a TDT is often supported by a facilitator. This can be someone from within the institution (e.g. Faas, 2009) or an external supporter (e.g. Handelzalts, 2009). For example, in the study of Faas (2012) the facilitator is an "internal designer" who thinks together with the team (not apart from the team) and guides them in the right direction. On the other hand, Handelzalts (2009) sees facilitators as "external experts" who provide the TDTs with new options and venues for development, thereby bringing in new knowledge and enriching the discussion.

Multiple studies have defined the role of the facilitator in different ways and attribute multiple roles to the facilitator (e.g. Faas, 2012; Fulton \& Britton, 2011; Handelzalts, 2009; Huizinga, Handelzalts, Nieveen \& Voogt, 2013a; Jenlink \& Kinnucan-Welsch, 2001; Marsh, Bertrand \& Huguet, 2015; Petrone \& Ortquist-Ahrens, 2004; Truijen, Sleegers, Meelissen, \& Nieuwenhuis, 2013). Huizinga, Handelzalts, Nieveen and Voogt (2013a) identified three gaps in teachers' design expertise (curriculum design expertise, pedagogical content knowledge and curricular consistency expertise) and formulated guidelines for facilitators to address them. According to these authors, it is crucial that TDTs receive support in every stage of the design process to address the lack of curriculum design expertise, especially during the analysis and evaluation stages, as TDTs experience most knowledge and skill-related problems while enacting these activities (Huizinga et al., 2013a). To prevent valuable time being lost in creating already 
available materials, it would seem usefulfor the facilitator to offer some technical support as well (Huizinga et al., 2013a). The facilitator can close the third gap (i.e., lack of curricular consistency expertise) by introducing activities to align the visions of the team members (Huizinga et al., 2013a).

In the study of Truijen, Sleegers, Meelissen and Nieuwenhuis (2013) managers adopted the role of facilitators in teacher teams in a vocational education context. These authors suggest that the support of a facilitator is most necessary when there is no natural leader in the team itself. Facilitators need to embrace transformational leadership, which leads to a shared vision and trust within the team (Truijen et al., 2013). They must help teams to determine their direction. According to Nieveen, Handelzalts, Van den Akker and Homminga (2005), a facilitator can provide pro-active support, helping to outline the design process, and re-active support, following the team's enacted design process. Facilitators determine the type of support based on the needs of the teams. Several studies show that the role of the facilitator depends on the situation (Patton et al., 2012), contextual boundaries (Huizinga et al., 2013a; Huizinga, Handelzalts, Nieveen, \& Voogt, 2015; Jenlink \& Kinnucan-Welsch, 2001) and the preferences of the facilitator (Huizinga et al., 2013a). Aligning teachers' and facilitators' preferences for support is vital, as it prevents conflicting expectations of the role of the facilitators (Nieveen et al., 2005).

\subsection{Process of facilitating}

Looking at the process of facilitating, Erikson, Brandes, Mitchell and Mitchell (2005) emphasize three important issues. First, there has to be consensus on the goal of the work, as sometimes teachers and facilitators have different agendas. Second, facilitators should introduce a formal theory in the work of the team. Providing the right tools can facilitate the design process (Linder, 2011). This should be done with the utmost care, as the theoretical perspective might not be embraced by teachers when it doesn't match with their practical perspective formed by class experiences. Third, it has to be clear who "owns" the team's agenda. Therefore, the facilitator needs to find a balance between the required and offered support (Huizinga et al., 2013a; Nieveen et al., 2005). This support should be offered just-in-time and as an integrated part of the design process (cf. Garet et al. 2001, Nieveen et al. 2005, Van Driel et al. 2012).

\subsection{Teacher educator design teams}


There is growing evidence about the potential benefits of TDTs for the professional development of teachers (e.g. Voogt, et al., 2015). However, much less is known about the implementation of this professional development strategy with teacher educators. Teacher educators must increasingly professionalize to ensure the quality of teacher education (Smith, 2003; Tack \& Vanderlinde, 2014). Also called "second order teachers", teacher educators not only teach a certain subject, they also teach others how to teach. Their tasks are therefore somewhat different from the tasks of a teacher (Loughran, 2014). It could therefore reasonably be argued that an important difference between the notion of professional development in relation to teachers and teacher educators is enmeshed in the sense of professional autonomy and responsibility attached to the respective roles and their accompanying expectations (Loughran, 2014). If teacher educators have different roles than teachers, questions arise about the implementation of TDTs that consist of teacher educators.

\section{Purpose of the study}

In the context of a professional development project for teacher educators, several TDTs were implemented in a teacher educator institution in Flanders. Each TDT consisted of three to four teacher educators and was supported by a facilitator from the same institution. The aim of the current study was to explore the different roles of a TDT facilitator of teams consisting of teacher educators. The current study therefore adds to the existing literature about the implementation of TDTs in teacher education institutions by contributing insights about the facilitation of teacher educator teams. The two main research questions guiding this study were:

1) What are the specific roles of the facilitator in a TDT?

2) What is the (perceived) importance of the facilitator in a TDT?

\section{Methodology}

\subsection{Descriptive case study}

To gain in-depth insight into the role of the facilitator, a case study was conducted in a teacher education institution. This was accomplished by collecting and triangulating the views of the participating teacher educators and the facilitators of three TDTs. Specifically, data were drawn from focus groups with participating teacher educators. 
Semi-structured interviews collected the perspectives of the facilitators (see Table 1 for an overview). We used the data collection from one source (i.e., teacher educators participating in TDT), to validate data from the other source, (i.e., facilitators of the TDTs) (Kimchi et al., 1991).

\subsection{Context of the study}

The case is situated in the context of a teacher education institution in Flanders, the Dutchspeaking part of Belgium. The implementation of TDTs in this institution originated from the specific training needs of teacher educators concerning technology-enhanced learning, (curriculum) research and assessment. Each of the TDTs had its own focus and worked together on a regular basis, though differing in intensities. Table 1 gives an overview of the respondents' characteristics. In the results section, more contextual information is given about each TDT.

Table 1 . Summary of respondents

\subsection{Instruments and analysis}

The focus group discussions provided the participants of the three TDTs a chance to talk about the affordances and limitations of working in their teams with a specific focus on the role of the facilitator. The researcher assured that discussions addressed the participants' views about the role and importance of the facilitator, and that all respondents were given sufficient opportunity to contribute their views. In order to triangulate the views of the teacher educators, in-depth interviews were conducted with the facilitators of the teams. Examples of questions are presented in Table 2.

Table 2. Examples of interview and focus group topics and questions.

All interviews and focus groups were audio recorded with the informed consent of participants. Next, case-specific data were first analyzed and then systematically subjected to cross-case analysis. A technique of inductive thematic analysis was used. Inductive codes were assigned to segments of data that described a new theme observed in the text (Miles \& Huberman, 1994). Finally, patterns and differences across the participants and facilitators from the different TDTs were identified through constant comparisons. 


\section{Results}

In this section, we describe the roles attributed to the facilitator and the perceived importance of the facilitator. For each case we present this from the viewpoint of the facilitator and the team members.

\subsection{Team A (Communicative Skills)}

The members of team A focused on "Communicative Skills". In the previous academic year, these three teacher educators taught specific topics concerning communicative skills to the same groups of students, and now wanted to use shared cases. The activities of the team were therefore focused on developing these shared cases and setting up a blog for the student teachers aimed at contributing to set goals for linguistic development in education. The facilitator of this TDT is an educational developer, mainly for technologyenhanced learning. He was assigned to this TDT because of his experience with ICT integration in language courses.

\subsubsection{Role of the facilitator}

The facilitator of team A enumerated several tasks for which he was responsible within his team. "Contacting external experts", "taking notes" and "reserving a conference room" were some administrative tasks he performed. He further tried to keep an eye on the process and to stimulate collaboration without being overbearing by "stimulating interaction and communication" and "structuring the process by asking questions and rephrasing what team members had said". There was one teacher educator in this team "who took on a leading role", and the facilitator confirms it was probably the best not to interrupt this process. The facilitator thought it would be better to follow the process instead of intervening: "I kept an eye on it from the sideline, rather informal, to avoid giving the impression of interfering too much, because that was not the intention. I just wanted something to happen, and if they could take action without lots of help, okay, no problem." Interestingly, the team members stated that they did not get any support from their facilitator: "We didn't see him; he was never there. But it wasn't a problem because we didn't need him." The facilitator also presented some design frameworks and tools to structure and facilitate the design process. However, the team members indicated that they didn't like the digital environment the facilitator provided at the start: "The digital environment proposed by the facilitator was not a good idea at all." 


\subsubsection{Perceived importance of the facilitator}

The teacher members of this team questioned the importance of a facilitator. "I didn't like it; why should he monitor us?", one of them asked. They said they would have preferred being supported by an expert. "If the facilitator had been a specialist, it would have been real quality support." The facilitator, in turn, felt that he wasn't welcomed into the team. He states:

"Having people skills are the most important skills a facilitator needs."

According to him, "You need people skills to sense what sort of support a TDT needs" and "A facilitator is important to provide structure to the collaboration and design process".

\subsection{Team B (Languages)}

Due to practical reasons, the facilitator of team A also supported team B, which consisted of one teacher educator who taught Dutch, one who taught French and one who taught English. As language teachers, they focused their design work on aligning their assessment principles. After informing themselves and getting advice from an external expert, they made up a visual representation of the relative importance of grammar, linguistic creativity and of teaching languages in relation to one another for each phase of the curriculum. This had the additional goal of making assessment clear and transparent for all language students throughout their training.

\subsubsection{Role of the facilitator}

The facilitator stated that he had more or less the same tasks in team B as he had in team A. He performed the administrative tasks. The members of team Languages mentioned that the facilitator indeed sent e-mails to arrange meetings and that he presented some useful design models to structure the design process. As with Team A, the facilitator monitored the process and supported the collaboration from the sideline. "It doesn't help to disturb the process at every turn," he said. He tried to record the process by posting it on a blog, as a form of an archive team members could return to. "Too much meddling is a trap facilitators have to be aware of," according to this facilitator. The team members said that the facilitator played an important role at the start: "He set us in motion, but further on, we didn't see him anymore. And that was okay." 


\subsubsection{Perceived importance of the facilitator}

According to the facilitator, he was more present during meetings in team B than he was in team A, because no-one emerged as a specific leader in team B. But he still offered subtle support, he said. The members of team B thought that a facilitator wasn't really necessary because teacher educators have enough experience working in a team without the support of a facilitator. "If a design team can't work on his own, it isn't a design team," said the members of the team. "If members of a design team don't agree on a shared goal, a facilitator will only push them, which would have a negative effect."

\subsection{Team C: Natural Sciences}

Team C focused on "Natural Sciences". Four teacher educators (one expert in biology, one in physics, two in bio-technics) joined forces in a TDT to integrate natural sciences into their own courses. They focused on content and on how to free up space in the TEI curriculum for a natural sciences course. Natural sciences is not a specific course in the TEI, although it has recently become part of secondary education curricula through the combination of several science subjects. The TEI's research coordinator acted as a facilitator for this team. At the time she was also the vice-dean of the TEI and wanted to facilitate a TDT because of her role in supporting innovation within the institution.

\subsubsection{Role of the facilitator}

The facilitator of the team Natural Sciences states: "Archiving and documenting the process were some of my tasks". She also mentions that she planned and facilitated events in the institution. She was involved in integrating 1) the TDT collaboration during professionalization days and 2) TDT presentations during meetings in the institution. Besides making it possible for a TDT to work together and presenting their work, this facilitator added that "team members proposed some content-related matters, and I needed to find out whether it was possible to program them." The team members also referred to the facilitator's organization of practical matters: "Our facilitator sent all the necessary e-mails, took care of arrangements and officially recorded our ideas".

Along with this logistic assistance, the facilitator promoted learning in the team by monitoring the process, as illustrated by her own words: "It was facilitating by providing the impetus to start and then keeping the process running by asking how it's going." The 
team members mentioned this too: "(When we were planning to meet, she said): No, , not next week, but this week. In that way, a facilitator can improve a team's efficiency as well." According to the facilitator, "adequate support at the beginning was necessary because they were not familiar with the methodology." It was particularly in the beginning, then, that this facilitator was present to get teachers started. The team members stated that "our facilitator brought the team together" and "she provided the incentive to collaborate".

The facilitator of team Natural Sciences added: "I gave process-oriented support, but I couldn't help them with content issues; that was not my task." Team members indicated as well that the facilitator structured the process by providing a framework: "When we were sitting together that day, she told us where to go, what to do: She provided a framework."

According to the facilitator, she sometimes needed to be a decision-maker as well: "A team is not always capable of taking decisions, and then the facilitator needs to do that."

\subsubsection{Perceived importance of the facilitator}

Regarding the perceived importance of the facilitator, the opinions of facilitator and team members are more or less the same. The facilitator of this team said that it is important that a TDT is supported by a facilitator. "Without a facilitator, it is too informal," she said. "A TDT needs someone who is available for support; a facilitator has an added value". The team members were also positive about the presence of the facilitator. Only once was the co-dean referred to as more important than the facilitator, as the co-dean had to take some institutional decisions. Teacher educators of this team, just like their facilitator, were convinced that the facilitator has an added value in a TDT, especially in teams that take less initiative. "A facilitator can increase efficiency," they stated. Generally, the team members concluded that their facilitator was a good leader: "She's a good leader. She does not do it in a very compelling way, but she's a leader all the same."

\section{Discussion and cross-case analysis}

The aim of this study was to find out what kind of support a facilitator can provide and how important a facilitator is according to team members and facilitators themselves. Based on a cross-case analysis, we can conclude that there are three roles a facilitator of 
a TDT consisting of teacher educators can fill: 1) providing logistic support, 2) scaffolding the design process and 3) monitoring the design process.

The results show that the usefulness of these roles depends on several factors: the design phase, team characteristics and team members' relationship with the facilitator. Each team, therefore, needs specific support depending on the context. The members of team A, for example, indicated they didn't need any support from their facilitator. This section ends with considerations for future research and practical implications.

\subsection{Roles of the facilitator}

\subsubsection{Providing logistic support}

In each TDT in this study, the facilitators provided logistical support in the practical organization of team activities, thereby adopting the role of administrator. The facilitator of the first two teams, for example, made external contacts, took notes, sent emails and reserved the conference room. The facilitator of Team $\mathrm{C}$ archived and documented the process. Team members confirmed that their facilitator took responsibility for archiving, corresponding with outside contacts and reporting. McLaughlin and Talbert (2014) also state that a facilitator should be able to coordinate and organize a TDT.

\subsubsection{Scaffolding the design process}

A facilitator supports a TDT by providing scaffolds to structure the process. This may be a formal framework to work with, a useful design model or an online learning environment to share information. Providing the right tools can facilitate the design process (Linder, 2011). In the cases studied, facilitators presented possible design models and digital tools that could structure the design process. The presented scaffolds weren't meant to be mandatory, just supportive. Nevertheless, Team A didn't like the scaffold they got from their facilitator. This is in line with the recommendations that Erikson et al. (2005) make. Facilitators should indeed introduce a formal theory in the work of the team but they should do this with the utmost care (Erikson et al., 2005).

\subsubsection{Monitoring the design process}

Next to providing logistic support and scaffolding the design process, facilitators also monitor the design process so the collaboration runs smoothly. Both facilitators in this 
study indeed address the importance of finding a balance between monitoring the design process and interrupting too often. They felt that teacher educators are able to act autonomous on many occasions. Team members indicated that they didn't need a facilitator and can work on their own. Therefore, both facilitators in this study felt that they need to be there to provide support when necessary but from outside the general discussion. Huizinga et al. (2013b) call this integrated just-in-time support. The authors advise facilitators to look for a balance between support that is offered and support that is requested.

\subsection{Perceived importance of the facilitator}

The value of a facilitator depends on several factors. The multiple roles a facilitator fulfills vary in importance throughout the design process and depend on the team, illustrated by Figure 1.

Fig. 1. Diverse roles of a TDT facilitator depending on several factors

\subsubsection{Impact of the design phase}

In this study, the facilitators indicated that the biggest part of their role was in the starting phase of the design process. A facilitator can provide the impetus to start the process. The importance of the facilitator in the starting phase is confirmed by several authors (e.g., Handelzalts, 2009; Huizinga et al., 2013a) who stress the importance of a facilitator during the entire design process, but particularly during the analysis (and evaluation) phase. The less familiar members of the team are with the concept of TDTs, the more support is needed at the start. However, although members of both Teams A and B said that the facilitator put the process in motion, they did not react to that positively.

\subsubsection{Influence of team characteristics}

The most striking finding in this study was how much the role of the facilitators differed depending on team characteristics. In one team, for example, a team member took the lead, so the facilitator didn't have to guide the team as a leader. This finding is consistent with previous research (e.g. Huizinga et al., 2013a; Jenlink \& Kinnucan-Welsch, 2001; Patton, Parker \& Neutzling, 2012). There are some common roles attributed to the facilitator of a TDT, but it seems that flexibility is the most important characteristic. This means that a facilitator adjusts the level of support to the needs of a specific TDT. Teams 
A and B were supported by the same facilitator, but he felt that he had to behave differently in each team. With just-in-time and hands-on support, a facilitator can respond to team characteristics and specific team needs. The Delphi study of Becuwe et al. (2016) also indicates that a flexible facilitator was perceived as important by multiple stakeholders involved in TDT.

\subsubsection{Relation between facilitator and team members}

In this study, two teams were rather negative about the presence of their facilitator, whereas the third team was more positive about the facilitator. The team with the positive attitude towards the facilitator, however, suggested that support by a facilitator is more important for teams that take less initiative. This is consistent with the idea that exists within teams that have a more negative attitude towards the facilitator: a facilitator is not necessary because teacher educators are capable enough to do it on their own. This is in line with Loughrans' (2014) definition of teacher educators as those who have more autonomy and control over their work than teachers per se, because they are "second order teachers". However, it's worth noting that the facilitators in this study were part of the institution, which might have raised some power issues. They were seen as peers and not as experts who could make a contribution to the team. This may be the reason team members said that they didn't need support from a facilitator. However, the negative perception may be due to personality characteristics of the facilitator as well instead of the perceived role of the facilitator. It is therefore difficult to attribute the perception of the role of the facilitator to the need of a facilitator perceived by the teacher educators.

Focus group conversations with both teams make clear that the support of the facilitator was considered not necessary, although one team really appreciated what their facilitator did. We can hypothesize that teams with a more negative attitude towards the facilitator have other basic assumptions about the role of the facilitator than teams who are more open to their presence. This suggests that some teams presume that the facilitator will be too controlling, while other teams view the facilitator as simply a member of the team.

We can consider a fourth factor influencing the perception of the facilitator: the task or goal of a TDT. Some tasks (e.g. aligning assessment principles may be of a different kind and require different external support - team B - than integrating natural sciences - team 
C) imply a different role for the facilitator and different expectations from the teacher educators.

\subsection{Considerations for future research}

Related to the conclusion that the role of a facilitator depends on the context, we can assume that not every TDT needs the same type of facilitator. The role of the facilitator and the importance of the facilitator depends on several factors, mentioned above. This study shows that teacher educators participating in a TDT are sometimes skeptical about the importance of a facilitator. They don't accept support by a facilitator because he/she doesn't have the expertise they expect, or they feel like they are autonomous enough to fulfill the design task on their own. Further research could investigate the implementation of TDTs in which teacher educators choose their own facilitators (this was not the case in our study), and what the effects of this are on the functioning of the team.

For this study, we do not know in what way teams succeeded in their assignment or task. Therefore, further research can focus on the relationship between the role of the facilitator (and in particular on the team's perception) and the effectiveness of teams. Will the effectiveness of the teams be dependent on the role of the facilitator and the team's perception of the facilitator? Research could also be conducted into whether successful teams are more positive about the role of the facilitator. Maybe teams attribute their success to their own functioning and their failure to the facilitator. Who is responsible for the success of the team: the facilitator, the team members or a combination of the two?

Huizinga et al. (2013a) identified a gap in teachers' design expertise. Support is important to address the lack of curriculum design expertise. However, in this study, facilitators only showed limited support in relation to design expertise. Therefore, in the extension of this study, TDT facilitators were supported through a trajectory. Facilitators who were part of that group stated that if they offered design-related support to their team, the team ended up with a more innovative design than teams of facilitators who felt excluded from the team. It would seem interesting to further investigate the impact of the facilitator on the innovativeness of a design and on the effectiveness of the team to accomplish the task in TDTs consisting of teacher educators.

\subsection{Practical implications}


The new project in which TDT facilitators were supported through a trajectory was influenced by the results of this study. The design of the trajectory was based on the question: "How do we train facilitators in supporting teacher design teams composed of teacher educators?" This study and other research show that the roles of a facilitator depend strongly on the context. Therefore, the designers of the facilitating trajectory provided enough meetings where facilitators participating in the bigger TDT project could exchange experiences and reflect on their role(s) as a facilitator in the specific context of their TDT. The facilitators felt the need to talk about how they fulfilled their roles, the challenges they faced and the issues they had to deal with.

Supporting a TDT as a facilitator is not an easy task. It requires compatible people who are able to respond to the needs of their TDT in a flexible way. Therefore, the implementation of a trajectory for facilitators would make sense in supporting facilitators who face a variety of challenges when supporting a TDT. We believe that the way facilitators support their team benefits from them having the opportunity to learn more about their different roles and reflect upon them. it benefits the whole team (Nelson, Slavit, Perkins, \& Hathron, 2008).

\section{Conclusion}

The implementation of TDTs is a type of demand-driven professional development strategy with teachers as active participants. When teacher educators collaborate in a TDT, the question arises as to what kind of support they need. Literature about TDTs consisting of teachers emphasizes the importance of the support of a facilitator. Since teacher educators have a double role (they not only teach a certain subject, they also teach others how to teach), we asked the question if they need a different kind of support. This study revealed that a facilitator can have five different roles, more or less in line with previous literature, when supporting a TDT consisting of teacher educators. The presence of the facilitator as administrator, communicator, moderator, facilitator or guiding leader depends on the design phase, team characteristics and the relationship that the facilitator has with team members. When facilitating a TDT consisting of teacher educators, the most important characteristic of a facilitator seems to be flexibility, something that is confirmed by other TDT research as well (Huizinga et al., 2013a; Jenlink \& KinnucanWelsch, 2001; Patton, Parker \& Neutzling, 2012). One way to prepare facilitators to effectively respond to the needs of a TDT is to create possibilities for them to share 
experiences and reflect about their role in a specific context. That way, they can learn from each other, and the TDTs become not only a professional development strategy for teacher(s) (educators) but also for the facilitators of these teams.

\section{References}

Agyei, D. D. (2012a). Preparation of pre-service teachers in Ghana to integrate information and communication technology in teaching mathematics. [Doctoraatsproefschrift] Enschede: Universiteit van Twente. Retrieved from http://doc.utwente.nl/80660/

Agyei, D. D., \& Voogt, J. (2012b). Developing technological pedagogical content knowledge in pre-service mathematics teachers through collaborative design. Australasian Journal of Educational Technology, 28 (4), 547-564. Retrieved from http://www.ascilite.org.au/ajet/ajet.html

Alayyar, G. M., Fisser, P., \& Voogt, J. (2012). Developing technological pedagogical content knowledge in pre-service science teachers: support from blended learning. Australasian Journal of Educational Technology, 28 (8), 1298-1316. Retrieved from http://ascilite.org.au/ajet/ajet.html

Angeli, C., \& Valanides, N. (2009). Epistemological and methodological issues for the conceptualization, development, and assessment of ICT-TPCK: Advances in technological pedagogical content knowledge (TPCK). Computers \& Education, 52 (1), 154-168. http://dx.doi.org/10.1016/j.compedu.2008.07.006

Bakah, M. A., Voogt, J. M., \& Pieters, J. M. (2012). Updating polytechnic teachers' knowledge and skills through teacher design teams in Ghana. Professional development in education, 38 (1), 7-24. DOI: 10.1080/19415257.2011.576265

Baskin, C., \& Williams, M. (2006). ICT-integration in schools: where are we now and what comes next? Australasian Journal of Educational Technology, 22 (4), 455-473. Retrieved from ICT-integration in schools: where are we now and what comes next?

Becuwe, H., Tondeur, J., \& Pareja Roblin, N. (2014). Een exploratieve casestudie naar de interacties tussen lerarenopleiders binnen Teacher Design Teams en de rol van de coach [masterproef]. Universiteit Gent, Gent. 
Becuwe, H., Pareja Roblin, N., Tondeur, J., Thys, J., Castelein, E., \& Voogt, J. (2015/2016). Conditions for the successful implementation of Teacher educator Design Teams for ICT-integration: A Delphi study. Australasian Journal of Educational Technology, ... (...), ...-... Doi:

Berry, A. (2013, July). Teacher educators' professional learning: A necessary case of "on your own"? Paper presented at the International Study Association on Teachers and Teaching (ISATT), Ghent, Belgium

Binkhorst, F., Handelzalts, A., Poortman, C., \& van Joolingen, W. (2015). Hoe werken docentontwerpteams? De ontwikkeling van een beschrijvend raamwerk. Paper presented at ORD, Leiden. Retrieved via e-mail.

Bruining, T. (2007). Didactische ergonomie voor leergemeenschappen. VELON tijdschrift voor lerarenopleiders, 1-20.

Cober, R., Tan, E., Slotta, J., So, H-J., \& Könings, K.D. (2015). Teachers as participatory designers: two case studies with technology-enhanced learning environments. Instructional Science, 43 (2). 203-228. http://dx.doi.org/10.1007/s11251-014-9339-0

Culatta, R. (2013). Instructional design models. In Instructional Design. Retrieved from http://www.instructionaldesign.org/models/

Diamond, I.R., Grant, R.C., Feldman, B.M., Pencharz, P.B., Ling, S.C., Moore, A.D., \& Wales, P.W. (2014). Defining consensus: a systematic review recommends methodologic criteria for reporting of Delphi studies. Journal of Clinical Epidemiology, 67 (4), 401-409. http://dx.doi.org/10.1016/j.jclinepi.2013.12.002

Doughty, E.A. (2009). Investigating adaptive grieving styles: a Delphi study. Death studies, 33 (5), 462-480. http://dx.doi.org/10.1080/07481180902805715

Ehrlenspiel, K., Giapoulis, A., \& Günther, J. (1997). Teamwork and design methodology: observations about teamwork in design education. Research in engineering design, 9 (2), 61-69. http://dx.doi.org/10.1007/BF01596482 
Erikson, G., Brandes, G.M., Mitchell, I. \& Mitchell, J. (2005). Collaborative teacher learning: findings from two professional development projects. Teaching and teacher education, 21 (7), 787-798. DOI: 10.1016/j.tate.2005.05.018

Faas, H. (2012). Het functioneren van een docentontwerpteam met een interne ontwerper/deskundige. (Niet-gepubliceerde masterproef). Universiteit Twente, Twente.

Frankenberger, E., \& Auer, P. (1997). Standardized observation of team-work in design. Research in engineering design, 9 (1), 1-9. http://dx.doi.org/10.1007/BF01607053

Fulton, K., \& Britton, T. (2011). STEM Teachers in Professional Learning Communities: From Good Teacher to Great Teaching. Washington, D.C: National Commission on Teaching and America's Future. Retrieved from http://www.wested.org/online_pubs/1098-executive-summary.pdf

Garba, S.A., Singh, T.K.R., \& Yusuf, N.M. (2013). Integrating technology in teacher education curriculum and pedagogical practices: the effects of web-based technology resources on pre-service teachers' achievement in teacher education training. Paper presented at the International conference on information science and technology application, Macau. Retrieved from https://www.google.be/search?q=ICISTA$13 \& \mathrm{rlz}=1 \mathrm{C} 1 \mathrm{KMZB}$ enBE568BE568\&oq=ICISTA13\&aqs=chrome..69i57.471j0j7\&sourceid=chrome\&es_sm=122\&ie=UTF-8. http://dx.doi.org/10.2991/icista.2013.14

Garet, M.S., Porter, A.C., Desimone, L., Birman, B.F., \& Yoon, K.S. (2001). What makes professional development effective? Results from a national sample of teachers. American Educational Research Journal, 38 (4), 915-945. DOI: $10.3102 / 00028312038004915$

Goktas, Y., Yildirim, S., \& Yildirim, Z. (2009). Main barriers and possible enablers of ICTs integration into pre-service teacher education programs. Educational technology and society, $12 \quad$ (1), 193-204. Retrieved from http://www.ifets.info/journals/12_1/15.pdf

Handelzalts, A. (2009). Collaborative curriculum development in Teacher Design Teams. Doctoral Thesis, University of Twente, Enschede. Retrieved from 
http://doc.utwente.nl/67385/1/thesis_A_Handelzalts.pdf

Hargreaves, A. (2011). Push, pull and nudge: the future of teaching and educational change. In X. Zhu \& K. Zeichner (Eds.) Preparing teachers for the $21^{\text {st }}$ century (217236). Berlin, Heidelberg: Springer.

Hipp, K.K., Huffman, J.B., Pankake, A.M., \& Olivier, D.F. (2008). Sustaining professional learning communities: case studies. Journal of educational change, 9 (2), 173-195. http://dx.doi.org/10.1007/s10833-007-9060-8

Hord, S.M. (1997). Professional learning communities: communities of continuous inquiry and improvement. Texas: Southwest educational development laboratory.

Hsu, C-C., \& Sandford, B.A. (2007). The Delphi technique: making sense of consensus. Practical assessment, research and evaluation, 12 (10), 1-8. Retrieved from http://pareonline.net/pdf/v12n10.pdf

Huizinga, T., Handelzalts, A., Nieveen, N., \& Voogt, J. (2013a). Teacher involvement in curriculum design: need for support to enhance teachers' design expertise. Journal of curriculum studies, 46 (1), 33-57.

http://dx.doi.org/10.1080/00220272.2013.834077

Huizinga, T., Handelzalts, A., Nieveen, N. \& Voogt, J. (2015). Fostering teachers' design expertise in teacher design teams: conducive design and support activities. Curriculum Journal, 26 (1), 137-163. DOI: 10.1080/09585176.2014.990395

Huizinga, T., Nieveen, N., Handelzalts, A., \& Voogt, J. (2013b). Ondersteuning op curriculumontwikkelexpertise van docentontwikkelteams. Pedagogische studiën, 90 (3), 4-20. Retrieved from http://doc.utwente.nl/88198/

Jenlink, P. M. \& Kinnucan-Welsch, K. (2001). Case stories of facilitating professional development. Teaching and Teacher Education, 17 (6), 705-724. doi:10.1016/S0742-051X(01)00025-7

Kay, R.H. (2006). Evaluating strategies used to incorporate technology into preservice education: A review of the literature. Journal of Research on Technology in Education, 38 (4),383-408. http://dx.doi.org/10.1177/0888406409346144 
Kimchi, J., Polivka, B., \& Stevenson, J. S. (1991). Triangulation: operational definitions. Nursing Research, 40(6), 364-366.

Knight, S.L, \& Lloyd, G.M., \& Arbaugh, F., \& Gamson, D., \& McDonald, S.P., \& Nolan Jr., J. (2014). Professional development and practices of teacher educators. Journal of teacher education, 65 (4), 268-270. http://dx.doi.org/10.1177/0022487114542220

Koster, B. (2003). Lerarenopleiders stellen eisen aan zichzelf. VELON tijdschrift voor lerarenopleiders, 24 (2), 23-32. Retrieved from http://www.lerarenopleider.nl/velon/blog/tijdschrift/j2003/lerarenopleiders-stelleneisen-aan-zichzelf/

Lawless, K.A., \& Pellegrino, J.W. (2007). Professional development in integrating technology into teaching and learning: knowns, unknowns, and ways to pursue better questions and answers. Review of educational research, 77 (4), 575-614. http://dx.doi.org/10.3102/0034654307309921

Lerarendirect (nd). Hoe worden uw leraren opgeleid? Online via http://www.ond.vlaanderen.be/schooldirect/bijlagen0102/evaluatieLO.htm

Lim, C.P., \& Lee, J.C.K. (2014). Teaching e-portfolios and the development of professional learning communities (PLCs) in higher education institutions. Internet and higher education, 20, 57-59. DOI: 10.1016/j.iheduc.2013.10.002

Linder, S.M. (2011). The facilitator's role in elementary professional mathematics professional development. Mathematics teacher education and development, 13 (2), 44-66.

Little, L.W. (1990). The persistence of privacy: autonomy and initiative in teachers' professional relations. Teachers college record, 91 (4), 509-536. Retrieved via email.

Loughran, J. (2014). Professionaly developing as a teacher educator. Journal of Teacher Education, 65 (4), 271-283. DOI: 10.1177/0022487114533386 
Marsh, J., Bertrand, M., Huguet, A. (2015). Using data to alter instructional practice: The mediating role of coaches and professional learning communities. Teachers College Record, 117, 1-40.

Martens, B. (2003). Informatica op school en in de lerarenopleiding. In: De Craemer J., Driesen J., Gombeir D., Gyselinckx F., Nijs R., van Braak J., Van den Vreken C., Willems P. (Eds.), ICT en onderwijsvernieuwing. Wolters-Plantyn, 103-124.

McKenney, S., Kali, Y., Markauskaite, L., \& Voogt, J. (2015). Teacher design knowledge for technology enhanced learning: an ecological framework for investigating assets and needs. Instructional science, 43 (2), 181-202. http://dx.doi.org/10.1007/s11251-014-9337-2

McLaughlin, M.W., \& Talbert, J.E. (2001). Professional communities and the work of high school teaching. Chicago: University of Chicago press.

Mishra, P., \& Koehler, M.J. (2006). Technological Pedagogical Content Knowledge: A Framework for Teacher Knowledge. Teachers College Record, 108 (6), 1017-1054. http://dx.doi.org/10.1111/j.1467-9620.2006.00684.x

Ministerial council on education, employment, training and youth affairs (2008). Melbourne Declaration on Educational Goals for Young Australians. Retrieved from http://www.educationcouncil.edu.au/site/DefaultSite/filesystem/documents/Reports \%20and\%20publications/Publications/National\%20goals\%20for\%20schooling/Natio nal_Declaration_on_the_Educational_Goals_for_Young_Australians.pdf

Nelson, T., Slavit, D., Perkins, M., \& Hathron, T. (2008). A culture of Collaborative Inquiry: Learning to Develop and Support Professional Learning Communities. Teachers College Record, 110 (6), 1269-1303.

Niess, M. L., Ronau, R. N., Shafer, K. G., Driskell, S. O., Harper S. R., Johnston, C., Browning, C., Özgün-Koca, S. A., \& Kersaint, G. (2009). Mathematics teacher TPACK standards and development model. Contemporary Issues in Technology and Teacher Education, 9 (1), 4-24. Retrieved from http://www.citejournal.org/vol9/iss1/mathematics/article1.cfm 
Nieveen, N., Handelzalts, A., Van den Akker, J. J. H., \& Homminga, S. (2005). Teacher design teams: A scenario for school-based curriculum innovation. Paper presented at the ECER 2005, Dublin, Ireland.

Okoli, C., \& Pawlowksi, S.D. (2004). The Delphi method as a research tool: an example, design considerations and applications. Information and management, 42 (1), 15-29. http://dx.doi.org/10.1016/j.im.2003.11.002

Patton, K., Parker, M., \& Neutzling, M.M. (2012). Tennis shoes required: the role of the facilitator in professional development. Research quarterly for exercise and sport, 83 (4), 522-532. DOI: 10.1080/02701367.2012.10599141

Paulus, P.B. (2000). Groups, teams and creativity: the creative potential of ideagenerating groups. Applied psychology: an international review, 49 (2), 237-262. http://dx.doi.org/10.1111/1464-0597.00013

Peeraer, J., \& Van Petegem, P. (2011). ICT in teacher education in an emerging developing country: Vietnam's baseline situation at the start of 'The year of ICT'. Computers and education, 56 (4), 974-982. http://dx.doi.org/10.1016/j.compedu.2010.11.015

Peeraer, J., \& Van Petegem, P. (2012). The limits of programmed professional development on integration of information and communication technology in education. Australasian Journal of Educational Technology, 28 (Special issue, 6), 1039-1056. Retrieved from http://ascilite.org.au/ajet/ajet.html

Petrone, M.C., \& Ortquist-Ahrens, L. (2004). Facilitating faculty learning communities: a compact guide to creating change and inspiring community. New directions for teaching and learning, 97, 63-69. http://dx.doi.org/10.1002/t1.133

Polly, D. (2011). Teachers' learning while constructing technology-based instructional resources. British journal of educational technology, 42 (6), 950-961. http://dx.doi.org/10.1111/j.1467-8535.2010.01161.x

Pounder, G.M. (2000). Interdisciplinary Teacher Teams: Context, Design, and Process. Educational Administration Quarterly, 36 (2), 216-254. doi: 10.1177/0013161X00362004 
Shaikh, Z.A., \& Khoja, S.A. (2014). Personal learning environments and university teacher roles explored using Delphi. Australasian Journal of Educational Technology, 30 (2), 202-226. Retrieved from http://ascilite.org.au/ajet/ajet.html

Simmie, M. G. (2007). Teacher Design Teams (TDTs)—building capacity for innovation, learning and curriculum implementation in the continuing professional development of in-career teachers. Irish Educational Studies, 26 (2), 163-176. DOI: $10.1080 / 03323310701295914$

Smith, K. (2003). So, what about the professional development of teacher educators. European Journal of Teacher Education, 26 (2), 201-215. http://dx.doi.org/10.1080/0261976032000088738

Somech, A., \& Drach-Zavary, A. (2007). Schools as team-based organizations: a structure-process-outcomes approach. Groups dynamics: theory, research and practice, 11 (4), 305-320. http://dx.doi.org/10.1037/1089-2699.11.4.305

Steketee, C. (2006). Modelling ICT-integration in teacher education courses using distributed cognition as a framework. Australasian Journal of Education Technology, 22 (1), 126-144. Retrieved from http://ascilite.org.au/ajet/ajet.html

Svihla, V., Reeve, R., Sagy, O., \& Kali, Y. (2015). A fingerprint pattern of supports for teachers' designing of technology-enhanced learning. Instructional science, 43 (2), 283-307. http://dx.doi.org/10.1007/s11251-014-9342-5

Tack, H., \& Vanderlinde, R. (2014). Teacher educators' professional development: towards a typology of teacher educators' researcherly disposition. British journal of educational studies, 62 (3), 297-315.

http://dx.doi.org/10.1080/00071005.2014.957639

Tondeur, J., Pareja Roblin, N., van Braak, J., Fisser, P., \& Voogt, J. (2013).

Technological Pedagogical Content Knowledge in teacher education: in search of a new curriculum. Educational Studies, 39 (2), 239-243. http://dx.doi.org/10.1080/03055698.2012.713548

Tondeur, J., van Braak, J., Sang, G., Voogt, J., Fisser, P., \& Ottenbreit-Leftwich, A. (2012a). Preparing pre-service teachers to integrate technology in education: A 
synthesis of qualitative evidence. Computers \& Education, 59 (1), 134-144. http://dx.doi.org/10.1016/j.compedu.2011.10.009

Tondeur, J., Pareja Roblin, N., \& Thys, J. (2012b). Teacher design teams als strategie voor ICT-integratie in de lerarenopleiding [slideshare]. Retrieved from http://www.slideshare.net/jtondeur

Truijen, K.J.P., Sleegers, P.J.C., Meelissen, M.R.M., Nieuwenhuis, A.F.M. (2013). What makes teacher teams in a vocational education context effective? A qualitative study of managers' view on team working. Journal of workplace learning, 25 (1), 58-73. http://dx.doi.org/10.1108/13665621311288485

Van Driel, J. H., De Jong, O., Verloop, N. (2002) The Development of Preservice Chemistry Teachers' Pedagogical Content Knowledge. Science Education, 86, 572590.

Vescio, V., Ross, D., \& Adams, A. (2008). A review of research on the impact of professional learning communities on teaching practice and student learning. Teaching and teacher education, 24 (1), 80-91. DOI: 10.1016/j.tate.2007.01.004

Voogt, J., Fisser, P., \& Tondeur, J. (2010). Maak kennis met TPCK. Hoe kan een leraar ict integreren in het onderwijs. Stichting Kennisnet: Zoetermeer, Nederland.

Voogt, J., Laferrière, T., Breuleux, A., Itow, R.C., Hickey, D.T., \& McKenney, S. (2015). Collaborative design as a form of professional development. Instructional science, 42 (2), 259-282. http://dx.doi.org/10.1007/s11251-014-9340-7

Voogt, J., \& Westbroek, H., \& Handelzalts, A., \& Walraven, A., \& McKenney, S., \& Pieters, J., \& de Vries, B. (2011). Teacher learning in collaborative curriculum design. Teaching and teacher education, 27 (8), 1235-1244. http://dx.doi.org/10.1016/j.tate.2011.07.003

Wenger, E. (2011). Communities of practice: A brief introduction. Available at: https://goo.gl/Rt4sCd

Wenger, E., McDermott, R., \& Snyder, W.M. (2002). A guide to managing knowledge: Cultivating communities of practice. Boston: Harvard business school press. 
Wentworth, N., Graham, C. R., \& Monroe, E. E. (2009). Linking stages of technological pedagogical content knowledge development through consistent evaluation criteria. In S. Ramanathan, Handbook of Research on New Media Literacy at the K-12 Level. Hershey, PA: Information Science Reference.

Whitcomb, J., Borko, H., \& Liston, D. (2009). Growing talent: promising professional development models and practices. Journal of Teacher Education, 60 (3), 207-2012. 
Table 1

Summary of respondents

\begin{tabular}{|c|c|c|c|c|c|}
\hline TDT & & Gender & $\begin{array}{l}\text { Years of } \\
\text { experience } \\
\text { in TEI }\end{array}$ & Position in TEI & Role in TDT \\
\hline \multirow[t]{3}{*}{$\begin{array}{l}\text { Communicative } \\
\text { Skills }\end{array}$} & respondent 1 & female & 5 & $\begin{array}{l}\text { teacher educator } \\
\text { Communication }\end{array}$ & participant \\
\hline & respondent 2 & female & 3 & $\begin{array}{l}\text { teacher educator } \\
\text { Communication }\end{array}$ & participant \\
\hline & respondent 3 & female & 12 & $\begin{array}{l}\text { teacher educator } \\
\text { Communication }\end{array}$ & participant \\
\hline \multirow[t]{3}{*}{ Languages } & respondent 4 & female & 9 & teacher educator French & participant \\
\hline & respondent 5 & male & 6 & teacher educator English & participant \\
\hline & respondent $6 *$ & female & 5 & teacher educator Dutch & participant \\
\hline $\begin{array}{l}\text { Communicative } \\
\text { Skills \& } \\
\text { Languages }\end{array}$ & respondent 7 & male & 12 & educational developer & coach \\
\hline \multirow[t]{5}{*}{ Natural Sciences } & respondent 8 & female & 9 & teacher educator Physics & participant \\
\hline & respondent 9 & female & 4 & teacher educator Biology & participant \\
\hline & respondent 10 & male & 23 & $\begin{array}{l}\text { teacher educator Bio- } \\
\text { technics }\end{array}$ & participant \\
\hline & $\begin{array}{l}\text { respondent } 11 \\
*\end{array}$ & female & 8 & $\begin{array}{l}\text { teacher educator Bio- } \\
\text { technics }\end{array}$ & participant \\
\hline & respondent 12 & female & 8 & research coordinator & coach \\
\hline
\end{tabular}

*not present during focus group discussion

Table 2

Examples of interview and focus group topics and questions.
Component
Question

a) Role of the coach Could you describe your role in the TDT?

Could you describe the role of the coach in your TDT?

b) Perceived

What role did you have in changing the practice?

importance of the

What role did the coach have in changing your practice? coach 


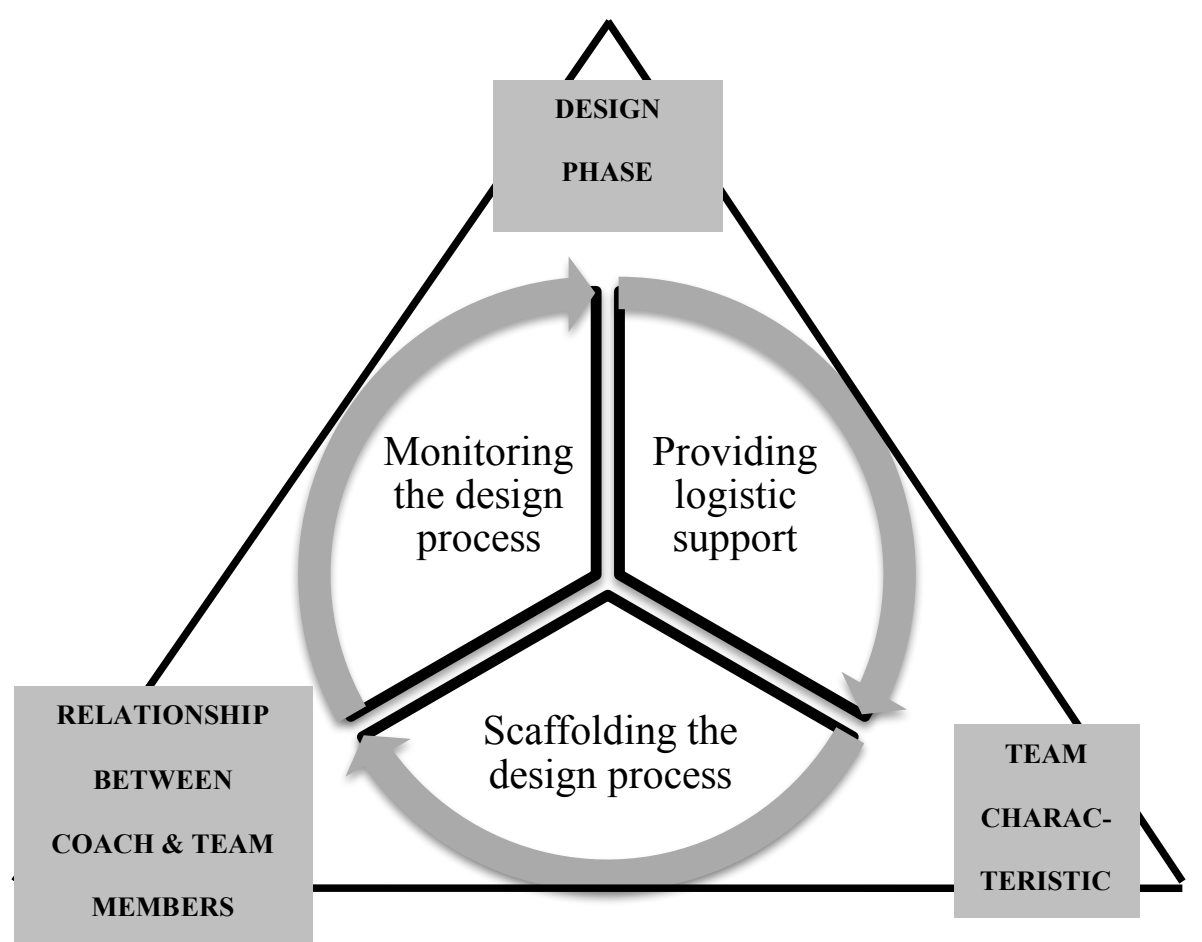

Fig. 1. Different roles of a TDT coach depending on several factors 